\title{
Measuring and Estimating Pressure-Saturation Curves on Undisturbed Soil Samples by Using Water and NAPL
}

\author{
A. MAKÓ \\ University of Veszprém, Georgikon Faculty of Agriculture, Keszthely (Hungary)
}

The ever increasing use of hydrocarbons requires huge storage and transport facilities. The threat of pollution caused by the presence of such installations and the reported cases of soil and groundwater pollution by accidental spillage has prompted an increased interest in the fate of petroleum products in soil and water (RUBIN et al., 1998). The hydrocarbon pollutants are present in liquids that are immiscible with water rather than in aqueous phase or sorbed to solids. The accurate prediction of the movement of non-aqueous phase liquid (NAPL) as a separate phase in vadose and groundwater zones is a prerequisite to the development of simulation models describing the migration and fate of organic contaminants in the subsurface.

The simulation of multiphase fluid flow in the subsurface of soil requires that the pressure-saturation $(P-S)$ relations of the porous medium be known for all fluid pairs. The measurement of the relevant P-S curves for two fluid- and, especially, three fluid media can be very time consuming or difficult. Therefore there is a paucity of primary P-S data for drainage systems representative of contaminated soils or subsoils. (There is even less information available for the primary imbibition P-S functions characterizing these environments (DEMOND \& ROBERTS, 1991)). Because of this, indirect methods - based on scaling and Leverett's assumption - are often used to predict P-S curves from data that are already available or can be measured more easily. Usually the P-S curves of airNAPL system are obtained by scaling the air-water system (LENHARD \& PARKER, 1987; FERRAND et al., 1990; BRADFORD \& LEIJ, 1995).

The appropriateness of this approach for handling the effect of the variation in interfacial force on capillary pressure-saturation relationships has been debated in the literature. The first point of contention is whether Leverett's function needs to include a dependence on the contact angle (ANDERSON, 1987; BRADFORD \& LEIJ, 1995; STEFFY et al., 1997). A second problem is whether

Correspondence to: Dr. András MAKÓ, University of Veszprém, Georgikon Faculty of Agriculture, Department of Soil Science. H-8360 Keszthely, Deák F. u. 16. Hungary. E-mail: h5551mak@ella.hu 
Leverett's function is capable of predicting the change in residual saturation of the wetting phase as a function of interfacial forces. Current usage of Leverett's function sidesteps much of this ambiguity by replacing saturation with "effective saturation" (PARKER et al., 1987; DEMOND \& ROBERTS, 1991).

Leverett proposed scaling P-S relations based on the assumption that the porous medium permeability and porosity are unchanged during the saturation with different fluids. It means that porous media are rigid and noninteracting (ideal porous medium). This assumption is not valid in clayey and/or in aggregated soils. Inadequate estimation of the NAPL retention may be a direct result of clay volume changes and soil aggregation changes when saturation with different fluids occurs (RUBIN et al., 1998; MAKÓ, 1999).

In light of problems that may be encountered in using Leverett's function, searches were made for alternative estimation techniques for P-S relationships. One of the possibilities is the adaptation of the widely used soil physical indirect method, in which the water retention is predicted using easily measurable soil properties.

GUPTA \& LARSON (1979), SCHUCH \& BAUDER (1986) used a statistical approach to find the correlation between particle size distribution and water retention characteristic curves. PUCKETT et al. (1985) were able to predict water retention curves successfully from textural data for soils covering large areas in the USA. AHUJA et al. (1985) tested a number of models that relate water retention to texture, structure, bulk density and organic matter content using published coefficients for their relationships. They found that the predicted water content values were generally higher than the measured ones, but that a great improvement could be obtained by including two measured water content values into the relationship. PUCKETT et al. (1995) pointed out that useful relations should only be expected for areas in which soils have similar mineralogy and genesis. A lot of other models exist describing the effect of soil texture, structure and other soil properties on water retention as well as hydraulic conductivity (e.g. NIMMO, 1999; ARYA et al., 1999).

On the basis of about 250 soil samples - mainly from the Great Hungarian Plain - RAJKAI et al. (1981) developed an evaluation technique for the calculation of water retention data from the texture and bulk density values of soils. This method was widely used in the categorization and mapping of hydrophysical properties and moisture regime of Hungarian soils (VÁRALLYAY, 1989).

The objective of this study was (1) to develop a technique for the routine measurement of the pressure-saturation curves of undisturbed soil samples saturated with NAPL; (2) to build a database using the measured P-S curves and the physical, chemical properties of the soils; and (3) to establish the dependence of NAPL retention on other soil properties. 


\section{Materials and Methods}

35 horizons of 12 soil profiles in Hungary were investigated. Taxonomically, this soil database contained Luvisols (4), Cambisols (3), Regosols (1), Gleysols (1), Vertisols (1), Solonetz (1) and Phaeosems (1). The soil horizons encompassed a wide range of texture, porosity, humus and lime content (Table 1).

Undisturbed soil samples $\left(100 \mathrm{~cm}^{3}\right)$ were collected from each horizon in six replicates.

Table 1

The origin and properties of soil samples studied

\begin{tabular}{|c|c|c|c|c|c|c|c|c|}
\hline \multirow[t]{2}{*}{ 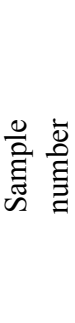 } & \multirow[t]{2}{*}{$\begin{array}{l}\text { FAO names } \\
\text { and name of } \\
\text { the closest } \\
\text { city }\end{array}$} & \multirow[t]{2}{*}{ 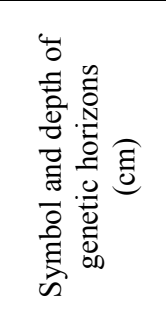 } & \multirow[t]{2}{*}{ 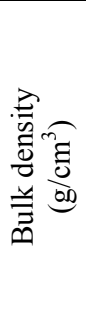 } & 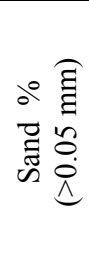 & 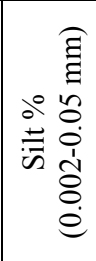 & 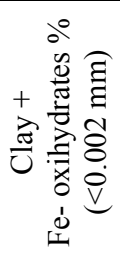 & 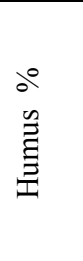 & $e_{\pi}^{m} 0^{\infty}$ \\
\hline & & & & \multicolumn{5}{|c|}{ Solid part of the soil $(100 \%)$} \\
\hline 1. & \multirow{4}{*}{$\begin{array}{l}\text { Eutric Regosols } \\
\text { Zalakomár }\end{array}$} & II. $20-33$ & 1.71 & 45.57 & 35.30 & 17.95 & 1.18 & 0 \\
\hline 2. & & III. 33-63 & 1.68 & 50.33 & 35.77 & 13.22 & 0.68 & 0 \\
\hline 3. & & IV. 63-104. & 1.60 & 52.37 & 31.86 & 15.31 & 0.46 & 0 \\
\hline 4. & & V. 104-122 & 1.63 & 51.29 & 29.76 & 17.23 & 0.82 & 0.9 \\
\hline 5. & \multirow{4}{*}{$\begin{array}{c}\text { Dystric Luvisols } \\
\text { Heresznye }\end{array}$} & A $0-39$ & 1.66 & 22.23 & 59.39 & 17.18 & 1.19 & 0 \\
\hline 6. & & B 39-65 & 1.60 & 21.19 & 54.91 & 23.24 & 0.66 & 0 \\
\hline 7. & & $\mathrm{C}_{1} 65-105$ & 1.63 & 15.35 & 50.69 & 33.60 & 0.36 & 0 \\
\hline 8. & & $\mathrm{C}_{2} 105-135$ & 1.63 & 31.73 & 46.28 & 21.84 & 0.15 & 0 \\
\hline 9. & \multirow{3}{*}{$\begin{array}{l}\text { Calcic Gleysols } \\
\text { Zalakaros I. }\end{array}$} & A $0-20$ & 1.15 & 21.80 & 24.35 & 37.20 & 5.66 & 11.0 \\
\hline 10. & & $\mathrm{~B}_{1} 20-47$ & 1.34 & 37.86 & 29.88 & 23.23 & 4.52 & 4.5 \\
\hline 11. & & $\mathrm{~B}_{2} 47-76$ & 1.38 & 35.46 & 31.67 & 29.96 & 1.21 & 1.7 \\
\hline 12. & \multirow{4}{*}{$\begin{array}{c}\text { Dystric Luvisols } \\
\text { Zalakaros II. }\end{array}$} & A 6-22 & 1.74 & 55.75 & 23.50 & 19.82 & 0.93 & 0 \\
\hline 13. & & B 22-43 & 1.75 & 46.37 & 21.03 & 32.23 & 0.37 & 0 \\
\hline 14. & & BC 43-54 & 1.62 & 38.03 & 30.69 & 31.02 & 0.26 & 0 \\
\hline 15. & & $\mathrm{C}_{2} 69-98$ & 1.40 & 5.00 & 63.07 & 31.59 & 0.34 & 0 \\
\hline 16. & \multirow{3}{*}{$\begin{array}{c}\text { Dystric Cambisols } \\
\text { Vízvár } I .\end{array}$} & A $0-23$ & 1.70 & 43.67 & 36.95 & 18.28 & 1.10 & 0 \\
\hline 17. & & $\mathrm{~B}_{1} 23-39$ & 1.74 & 39.51 & \begin{tabular}{|l|}
38.32 \\
\end{tabular} & 21.59 & 0.57 & 0 \\
\hline 18. & & $\mathrm{~B}_{2} 39-68$ & 1.65 & 36.18 & 36.65 & 26.73 & 0.43 & 0 \\
\hline 19. & \multirow{3}{*}{$\begin{array}{c}\text { Dystric Cambisols } \\
\text { Vízvár II. }\end{array}$} & A $0-35$ & 1.60 & 41.27 & 32.62 & 24.66 & 1.46 & 0 \\
\hline 20. & & B $35-57$ & 1.67 & 44.29 & 35.73 & 19.46 & 0.53 & 0 \\
\hline 21. & & BC 57-79 & 1.60 & 43.55 & 32.16 & 23.97 & 0.31 & 0 \\
\hline 22. & $\begin{array}{c}\text { Orthic Luvisols } \\
\text { Nagyrécse }\end{array}$ & B $20-35$ & 1.51 & 6.91 & 54.64 & 36.72 & 1.72 & 0 \\
\hline
\end{tabular}


Table 1 continued

\begin{tabular}{|c|c|c|c|c|c|c|c|c|}
\hline \multirow[t]{2}{*}{ 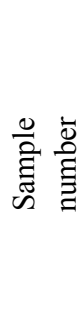 } & \multirow[t]{2}{*}{$\begin{array}{l}\text { FAO names } \\
\text { and name of } \\
\text { the closest } \\
\text { city }\end{array}$} & \multirow[t]{2}{*}{ 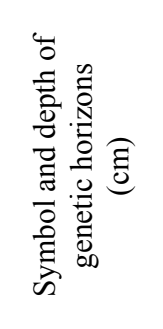 } & \multirow[t]{2}{*}{ 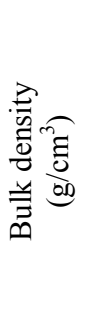 } & 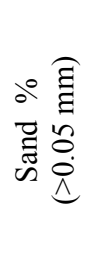 & 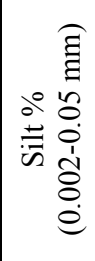 & 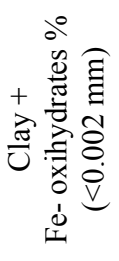 & 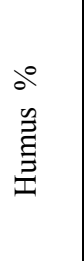 & $e_{U^{\pi}}^{m} a^{0}$ \\
\hline & & & & \multicolumn{5}{|c|}{ Solid part of the soil $(100 \%)$} \\
\hline 23. & $\begin{array}{c}\text { Orthic Solonetz } \\
\text { Karcag } \\
\end{array}$ & B $20-40$ & 1.44 & 0.49 & 34.84 & 62.52 & 2.05 & 0.1 \\
\hline 24. & $\begin{array}{c}\text { Gleyic Calcic } \\
\text { Vertisols } \\
\text { Kisújszállás }\end{array}$ & A $0-20$ & 1.50 & 0.42 & 40.48 & 55.39 & 3.71 & 0 \\
\hline 25. & \multirow{4}{*}{$\begin{array}{c}\text { Eutric Cambisols } \\
\text { Keszthely }\end{array}$} & A $0-25$ & 1.73 & 35.58 & 27.88 & 34.81 & 1.73 & 0 \\
\hline 26. & & $\mathrm{~B}_{1} 25-40$ & 1.66 & 34.00 & 34.46 & 30.73 & 0.81 & 0 \\
\hline 27. & & $\mathrm{~B}_{2} 40-62$ & 1.52 & 31.66 & 37.31 & 30.21 & 0.81 & 0 \\
\hline 28. & & BC $62-87$ & 1.51 & 29.64 & 39.97 & 29.87 & 0.52 & 0 \\
\hline 29. & \multirow{3}{*}{$\begin{array}{l}\text { Calcic Phaeosems } \\
\text { Lovasberény }\end{array}$} & A $0-45$ & 1.40 & 19.71 & 42.60 & 22.50 & 3.19 & 12.0 \\
\hline 30. & & B $45-73$ & 1.27 & 12.57 & 55.75 & 16.88 & 1.64 & 13.2 \\
\hline 31. & & BC 73-104 & 1.18 & 12.71 & 40.50 & 15.66 & 1.13 & 30.0 \\
\hline 32. & \multirow{4}{*}{$\begin{array}{l}\text { Gleyic Luvisols } \\
\text { Magyarszombatfa }\end{array}$} & A $0-21$ & 1.59 & 5.59 & \begin{tabular}{|l|}
55.07 \\
\end{tabular} & 37.81 & 1.53 & 0 \\
\hline 33. & & $\mathrm{~B}_{1} 21-47$ & 1.60 & 3.69 & 45.18 & 50.53 & 0.60 & 0 \\
\hline 34. & & $\mathrm{~B}_{2} 47-79$ & 1.61 & 4.18 & 43.05 & 52.45 & 0.33 & 0 \\
\hline 35. & & C 79-105 & 1.57 & 3.66 & 47.84 & 48.15 & 0.36 & 0 \\
\hline
\end{tabular}

Particle size fraction percentages were measured by the conventional pipette method. The full desaggregation procedure was made according to the ISO/DIS 11277/1995 standard. Other soil characteristic determinations followed standard methods (BúZÁs, 1993). (Dry bulk density was used and was assumed to be constant within the whole suction range.)

The P-S curves with water ( $\mathrm{pF}$ curves) were measured according to the Hungarian standard at 8 suction values (VÁRALLYAY, 1973). At $\mathrm{pF}$ values of 0 to $2.5100 \mathrm{~cm}^{3}$ water saturated soil core samples were exposed to suction in boxes containing sand and kaolin plates. $\mathrm{pF} 3.4$ and $\mathrm{pF} 4.2$ values were determined on resaturated soil pastes in pressure membrane apparatus with cellophane membranes. The $\mathrm{pF} 6.2$ values were calculated from hygroscopic measurements applying a relative humidity of $34 \%$ above the samples (set using $\left.\mathrm{CaCl}_{2} \cdot 6 \mathrm{H}_{2} \mathrm{O}\right)$. 
The P-S curves with NAPL were determined using a modified pressure cell apparatus (Soilmoisture Equip.Corp., LAB 023) (KLUTE, 1986; MAKÓ, 1999). The wetting phase was a non-aromatic hydrocarbon distillation product, namely DUNASOL 180/220 (Table 2).

Table 2

Characteristic physical and chemical properties of the liquids used in the measurements

\begin{tabular}{|l|c|c|}
\hline \multicolumn{1}{|c|}{ Fluid properties } & Distilled water & NAPL: \\
DUNASOL 180/220
\end{tabular}

Since the NAPL/air interfacial tension decreases significantly with increasing temperature, the temperature was set at $20^{\circ} \mathrm{C}$. Two types of porous ceramic plates were used (1.0 bar and 5.0 bar air entry value for water, originated from Soilmoisture Equip. Corp.). Pressure cells were designed and constructed in the laboratory of our department using the porous ceramic plates and oil-resistant silicon rubber. The materials of all accessories were Teflon and glass. Five different gas pressures were applied during the measurements $(0.002 ; 0.1 ; 0.2 ; 0.5$ and $1 \mathrm{bar}$. For the examined samples a week equilibration time was found sufficient (Figure 1).

In order to compare the P-S curves measuring with different methods and fluids, the following three parameter functions were fitted to them (VÁrALlyAY et al., 1979):

$$
\theta / \theta_{\mathrm{o}}=1 /\left[1+\left(\mathrm{X} / \mathrm{X}_{\mathrm{o}}\right)^{\mathrm{b}}\right]
$$

where $\theta_{\mathrm{o}}, \mathrm{X}_{\mathrm{o}}$ and $\mathrm{b}$ are experimental constants; $\theta$ is the fluid content (vol\%); $\mathrm{X}$ is pressure (bar). 


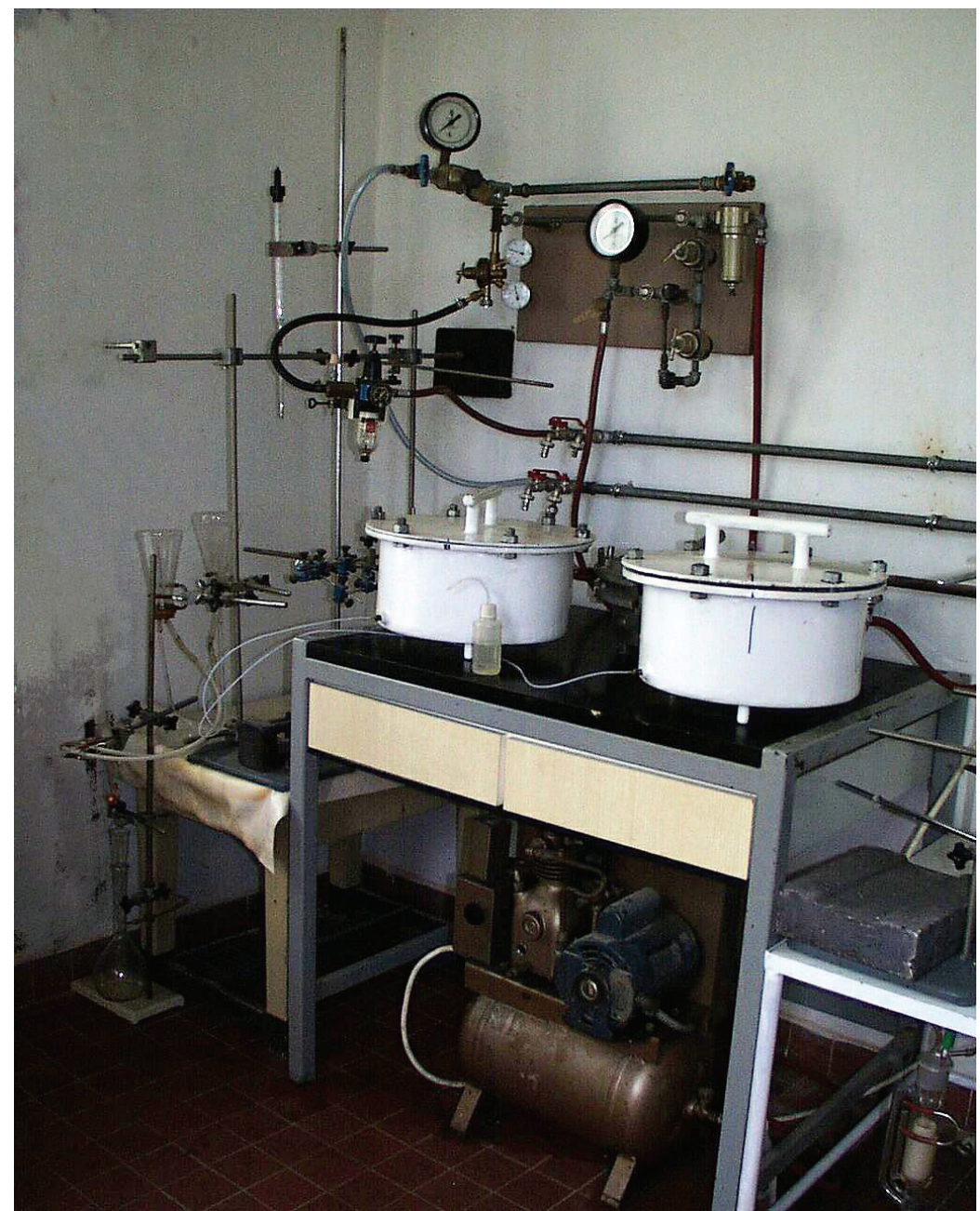

Figure 1

The modified pressure cell apparatus constructed by the author for the measurements of the NAPL retention

For the selection of the soil variables best correlated to the points of P-S curves measured with NAPL, backward regression analysis was used. After determining the independent variables best correlated to retained NAPL amounts the following regression function was fitted by multiple linear regression (RAJKAI et al., 1981):

$$
\mathrm{Y}=\mathrm{b}_{0}+\mathrm{b}_{1} \mathrm{X}_{1}+\mathrm{b}_{2} \mathrm{X}_{2}+\mathrm{b}_{3} \mathrm{X}_{1} \mathrm{X}_{2}+\mathrm{b}_{4} \mathrm{X}_{1}^{2}+\mathrm{b}_{5} \mathrm{X}_{2}^{2}
$$

where $b_{0}-b_{5}$ are regression coefficients; $X_{1}$ is explanatory variable at the first place; $\mathrm{X}_{2}$ is explanatory variable at the second place. 


\section{Results and Discussion}

The results of pressure-saturation measurements with different fluids were not comparable, because of the different pressure values used with the different methods. Therefore a three parameter function (Eq. 1) was fitted to the measured NAPL content values in order to compare the water and NAPL retention at a given pressure. The $\mathrm{R}^{2}$ values $(>0.90)$ suggest that the applied function is suitable for the description of the pressure-NAPL content curves measured with water and NAPL. Due to that reason the calculated values using this function can be used successfully instead of the measured data in further statistical examination.

Figure 2 shows a plot of NAPL retention data versus water retention data. As the relationship between the NAPL and water retention is not too strong $\left(\mathrm{R}^{2}=\right.$ 0.71), a Leverett-type scaling of the water retention data can give - in some cases - inadequate estimation of the NAPL retention.

The results of backward regression and the applied multiple linear regression of (Eq. 2) are summarized in Table 3. It can be seen that in the low suction range $(0.1 \mathrm{bar}>)$ the silt content and the bulk density are the determining soil variables. In the higher suction range first the sand and clay content, then the sand and humus content are decisive.

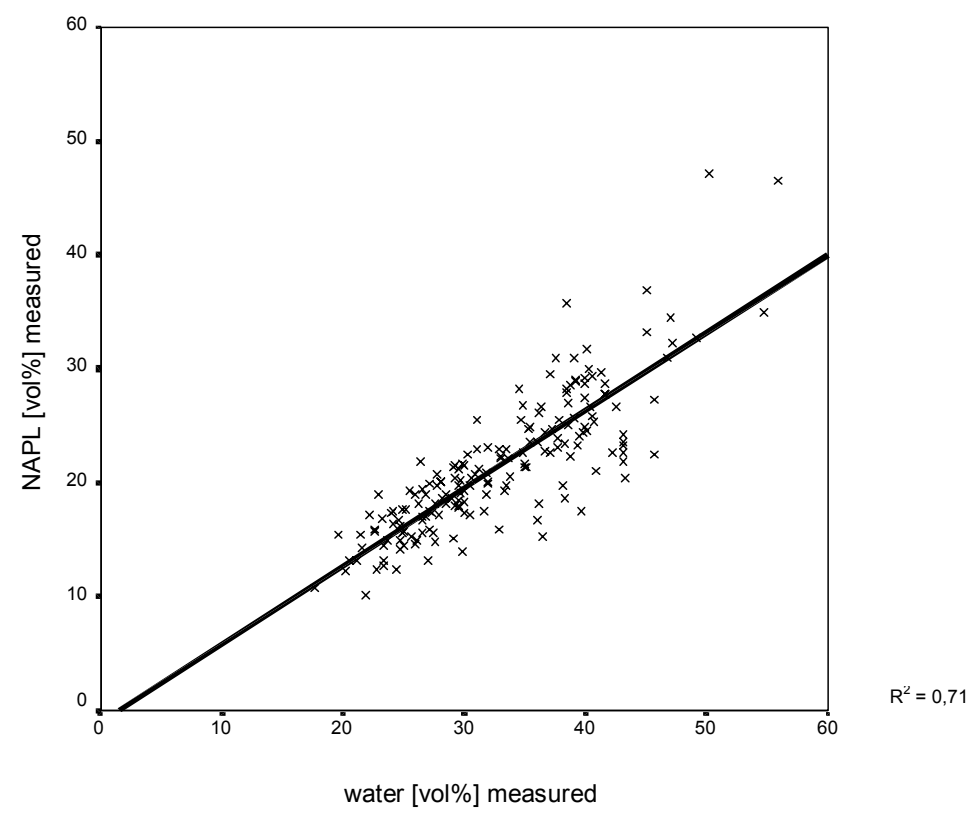

Figure 2

Relationship of measured (horizontal axis) and predicted (vertical axis) oil content retained by the soil samples 
Table 3

Results of regression analysis of NAPL retention values and selected soil properties (particle size distribution, humus content, bulk density)

\begin{tabular}{|c|c|c|c|c|c|c|c|c|c|c|}
\hline \multicolumn{10}{|c|}{$\mathrm{Y}=\mathrm{b}_{0}+\mathrm{b}_{1} \mathrm{X}_{1}+\mathrm{b}_{2} \mathrm{X}_{2}+\mathrm{b}_{3} \mathrm{X}_{1} \mathrm{X}_{2}+\mathrm{b}_{4} \mathrm{X}_{1}^{2}+\mathrm{b}_{5} \mathrm{X}_{2}^{2}$} \\
$\begin{array}{c}\text { Pres- } \\
\text { sure } \\
\text { (bar) }\end{array}$ & $\mathrm{X}_{1}$ & $\mathrm{X}_{2}$ & $\mathrm{R}^{2}$ & $\mathrm{~N}$ & $\mathrm{~b}_{0}$ & $\mathrm{~b}_{1}$ & $\mathrm{~b}_{2}$ & $\mathrm{~b}_{3}$ & $\mathrm{~b}_{4}$ & $\mathrm{~b}_{5}$ \\
\hline 0 & $\mathrm{SI}$ & $\mathrm{BD}$ & 0.842 & 96 & 69.945 & 1.862 & -68.831 & -0.675 & $-8.620 \mathrm{E}-03$ & 21.181 \\
0.1 & $\mathrm{SA}$ & $\mathrm{CL}$ & 0.654 & 96 & 29.248 & -0.300 & $-7.16 \mathrm{E}-02$ & - & $2.160 \mathrm{E}-03$ & - \\
0.2 & $\mathrm{SA}$ & $\mathrm{HUM}$ & 0.706 & 96 & 25.940 & -0.336 & -0.742 & $3.401 \mathrm{E}-02$ & $2.638 \mathrm{E}-03$ & - \\
0.5 & $\mathrm{SA}$ & $\mathrm{HUM}$ & 0.723 & 96 & 25.609 & -0.400 & -1.172 & $4.629 \mathrm{E}-02$ & $3.616 \mathrm{E}-03$ & - \\
1 & $\mathrm{SA}$ & $\mathrm{HUM}$ & 0.711 & 96 & 25.375 & -0.419 & -1.140 & $4.723 \mathrm{E}-02$ & $3.854 \mathrm{E}-03$ & - \\
\hline
\end{tabular}

$\mathrm{Y}$ : NAPL retention [vol\%]; $\mathrm{b}_{0}-\mathrm{b}_{5}$ : parameters of the regression equation; $\mathrm{X}_{1}-\mathrm{X}_{2}$ : explanatory variables at the first and second place; $\mathrm{R}^{2}$ : coefficient of determination; $\mathrm{N}$ : sample number; CL: clay\%; SI: silt\%; SA: sand\%; HUM: humus; BD: bulk density, g/ $\mathrm{cm}^{3}$

By the application of the linear regression equations of Table 3 the points of pressure-NAPL content curves can be calculated directly from the mechanical fractions, bulk density and humus content values of the soil in question. The

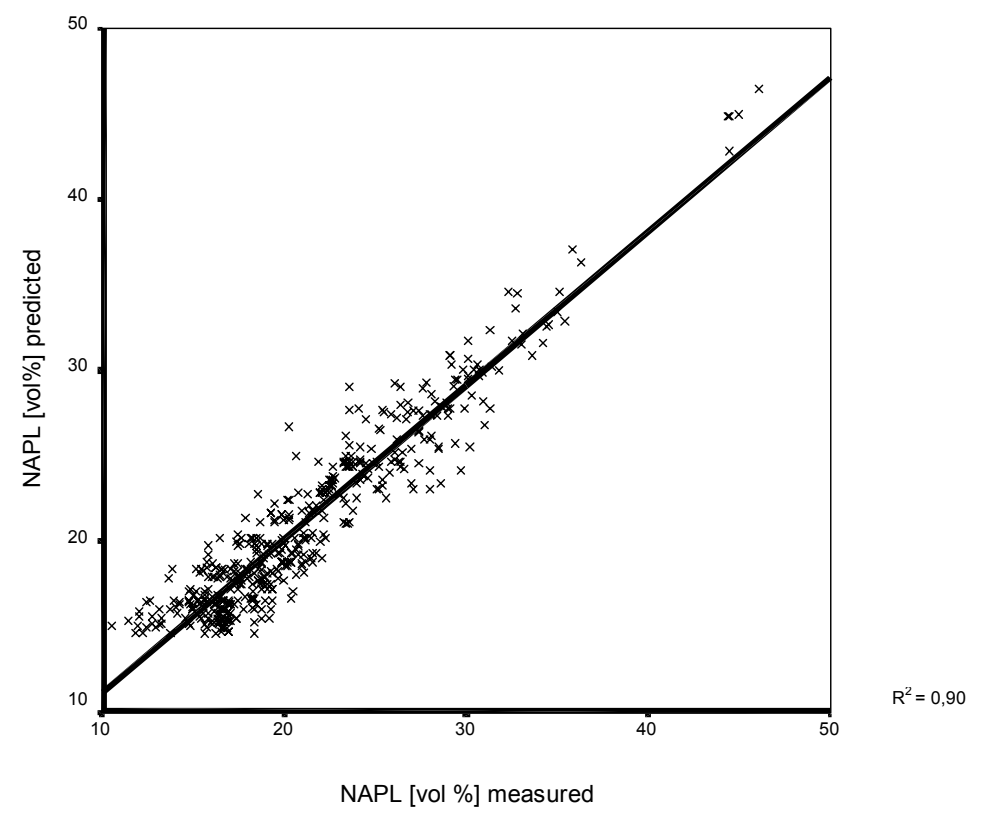

Figure 3

Relationship of measured and predicted NAPL content retained by the soil samples Prediction: using the regression equations of Table 3 
relationship of measured and calculated NAPL retention values is presented by Figure 3. As it can be seen from this plot, the measured and estimated NAPL retention data agree fairly well $\left(\mathrm{R}^{2} \sim 0.9\right)$. This estimation method (after extending the database) can be useful for modelling NAPL fate and migration or mapping the organic contaminant sensitivity of the soils.

\section{Summary}

In order to expand the experimental data set of models describing the movement of organic liquids polluting the soils, a series of experiments was set up in which the fluid retention (pressure-saturation curves of the soils) were measured using water and NAPL (DUNASOL 180/220, a non aromatic petroleum product). Measurements were carried out on undisturbed soil samples originating from 35 different horizons of 12 characteristic Hungarian soils. The P-S curves with NAPL were determined in series, by a modified pressure cell apparatus - designed and constructed in the laboratory of our department - containing oil-resistant (silicon rubber, Teflon) components.

The applied methodology and the statistical analysis of the measured data are presented. The results show that the commonly used Leverett-type scaling of the water retention data provides inadequate estimation of the NAPL retention in some cases. This deviation may be a direct result of changes in clay volume and soil aggregation when saturation with different fluids was performed.

According to the analysis, however, with the easily measurable soil parameters (bulk density, particle size distribution and humus content) a better estimation of NAPL retention can be given. This estimation method (after extending the database) can be useful for modelling the fate and migration of NAPL or mapping the organic contaminant sensitivity of the soils.

Key words: pressure-saturation curves, NAPL, undisturbed soil samples, estimation, modelling

\section{References}

Ahuja, L. R., NANey, J. W. \& Williams, R. D., 1985. Estimating soil water characteristics from simpler properties or limited data. Soil Sci. Soc. Am. J. 49. 1100 1105.

ANDERSON, W. G., 1987. The effect of wettability on capillary pressure. Wettability literature survey. 4. Journal of Petroleum Technology. 39. 1283-1300.

ARYA, L. M., LeIJ, F. J. \& VAN GENUCHTEN, M. TH., 1999. Relationship between particle-size distribution and soil water retention. In: Proc. Int. Workshop on Characterization and Measurement of the Hydraulic Properties of Unsaturated Porous Media, Riverside, 22-24 Oct, 1997. (Eds.: VAN GENUCHTEN et al.) 931-946. 
BRADFORD, S. A., LeIJ, F. J., 1995. Wettability effects on scaling two- and three-fluid capillary pressure-saturation relations. Environ. Sci. Technology. 29. 1446-1455.

BuzÁs, I. (Ed.), 1993. Methods of Soil Analysis. Part 1-2. (In Hungarian) INDA. Budapest.

Demond, A. H. \& RoberTs, P. V., 1991. Effect of interfacial forces on two-phase capillary pressure-saturation relationships. Water Resources Res. 27. 423-437.

FERRAND, L. I. et al., 1990. A comparison of capillary pressure-saturation relations for drainage in two- and three-fluid porous media. Advanced Water Res. 13. 54-63.

GuPTA, S. C. \& LARSON, W. E., 1979. Estimating soil water retention characteristics from particle-size distribution, organic matter percent and bulk density. Water Resources Res. 15. 1633-1635.

KLUTE, A., 1986. Water retention: laboratory methods. In: Methods of Soil Analysis. 1. Physical and Mineralogical Methods. (Eds: KluTE, A.) 635-662. ASA. Madison.

LENHARD, R. J. \& PARKER, J. C., 1987. Measurement and prediction of saturation-pressure relations in three phase porous media systems. J. Contam.Hydr. 1. 407-424.

MAKÓ, A., 1999. Measuring the soil physical parameters of clayey soils using NAPLs. European Geophysical Society XXIV General Assembly, The Hague, Netherlands, 19-23 April 1999. Geophysical Research Abstracts. 1. (2) 336.

NIMMO, J. R., 1999. Predicting soil-water retention and hydraulic conductivity from textural and structural information. In: Proc. Int. Workshop on Characterization and Measurement of the Hydraulic Properties of Unsaturated Porous Media, Riverside, 22-24 Oct, 1997. (Eds.: VAN GENUCHTEN et al.) 923-930.

PARKer, J. C., LENHARD, R. J. \& KupPuSAMY, T., 1987. A parametric model for constitutive properties governing multiphase flow in porous media. Water Resources Res. 23. 618-624.

Puckett, W. E., DANe, J. H. \& HAJEK, B. F., 1985. Physical and mineralogical data to determine soil hydraulic properties. Soil Sci. Soc. Am. J. 49. 831-836.

RAJKAI, K. et al., 1981. Calculation of water retention data from the texture and the bulk density of soils. (In Hungarian) Agrokémia és Talajtan. 30. 409-438.

Rubin, H., NARKIS, N. \& CARBerRY, J., 1998. Soil and Aquifer Pollution. Nonaqueous Phase Liquids - Contamination and Reclamation. Springer Verlag. Berlin.

SCHUCH, W. M. \& BAUDER, J. W., 1986. Effect of soil properties on hydraulic conductivity-moisture relationships. Soil Sci. Soc. Am. J. 50. 848-855.

StefFy, D. A., BARRY, D. A. \& JohnSTON, C. D., 1997. Improved scaling technique for two-phase pressure-saturation relationships. J. Contam. Hydr. 28. 207-225.

VÁRALlYAY, GY., 1973. Soil moisture potential and a new apparatus for the determination of moisture retention curves in the low suction range (0-1 atmosphere) (In Hungarian) Agrokémia és Talajtan. 22. 1-22.

VÁRALLYAY, GY., 1989. Mapping of hydrophysical properties and moisture regime of soils. Agrokémia és Talajtan. 38. 800-817.

VÁRALLYAY, GY. et al., 1979. Mathematical description of water retention curves. (In Hungarian) Agrokémia és Talajtan. 28. 15-38. 